\title{
Membrane bioreactors for wastewater treatment: A review of microbial quorum sensing and quenching to control membrane biofouling based on engineering quorum quenching bacteria
}

\author{
Xinmeng Jiao ${ }^{l}$, Kang Xie ${ }^{l, *}$, and Liping Qiu ${ }^{l}$ \\ 1School of Civil Engineering and Architecture, University of Jinan, Jinan, Shandong Province, PR China,250022.
}

\begin{abstract}
Membrane bioreactor (MBR) is a kind of reputable and prospective technology for wastewater treatment and reformation applications. However, membrane fouling caused by the formation of biofilm on the membrane surface, especially biofouling, is a major obstacle that limits the energy-saving operation and maintenance of the membrane bioreactor (MBR). Microbial communication (known as Quorum Sensing $(\mathrm{QS})$ ) is the cause of this fouling phenomenon. A new strategy called Quorum Quenching (QQ) seems to have been successfully used for biological pollution control in wastewater treatment MBR. This review summarizes the latest findings regarding membrane fouling, QS mechanisms and QQ applications. We discussed the opportunities for further practical application of self-cleaning engineering QQ bacteria in MBR.
\end{abstract}

\section{Introduction}

The best wastewater after treatment is water with low content of organic pollutants and free of pathogens, bacteria and viruses. Therefore, reliable, effective and efficient treatment methods are needed. ${ }^{[1]}$. Membrane bioreactor (MBR) is a powerful separation and treatment system, which is superior to traditional wastewater treatment (WWT) systems, such as simple flow configuration, stable and high wastewater quality, large volume load, and residual sludge generation Low biomass concentration and avoid sludge settling ${ }^{[2]}$.

However, membrane fouling remains a major problem that hinders its wider and large-scale application. Membrane fouling will increase the transmembrane pressure (TMP) and reduce the osmotic flux, resulting in the addition of operating costs and energy consumption. Methods specifically designed to prevent scaling in MBR operations can be roughly divided into five methods: 1 ) physical treatment of the input material, 2) physical and chemical cleaning of the membrane, 3) reduction of flux, 4) increase of ventilation 5) Chemical or biochemical modification of the mixture ${ }^{[3]}$. Nonetheless, these methods have little effect on mitigating the membrane biofouling.

In recent years, the QS and QQ strategies have been found and identified to reduce membrane biofouling. Quorum Sensing (QS) is a word used to describe an environmental sensing system that allows microorganisms to synchronize their gene expression and physiological behavior in a manner that depends on cell density. It is mediated by small molecule signaling chemicals called auto-inducers (AI). These chemical components are constitutively synthesized in the cell, and then passively or actively exchanged with the surrounding environment. The accumulation of signal molecules is proportional to the increase in the number of bacteria. When the signal reaches a threshold concentration, the homologous receptor binds to the signal and triggers a cascade of signal transduction reactions, causing its gene expression to change throughout the population ${ }^{[4]}$. Quorum quenching (QQ), a confrontational method of quorum sensing refers to a process that can impede and disrupt AIs-based quorum sensing to inhibit gene expression that mediates bacterial behaviors $^{[5]}$.

Here, we summarized microbial QS signaling molecules, kinds of QQ methods, and the engineering application of biological pollution control in MBR.This paper provides perceptions into the prospect of QS and QQ strategies for biofouling alleviation techniques in the further.

\section{Membrane fouling and control strategies}

During the last decades, a large number of published articles on different aspects of membrane fouling and antifouling strategies. Majid Bagheri et al. analyzed more than 150 publications, covering factors that affect membrane fouling, such as membrane materials, sludge characteristics, and operating parameters and etc., and membrane antifouling such as mechanical/ chemical cleaning, biological methods and electrically-based approaches $^{[1]}$. Meng et al offered an updated review on the fouling in membrane bioreactors and emerging 
fouling alleviation ways. The underlying causes of membrane fouling control were highlighted on optimization and enhancement of aeration scouring, chemical cleaning, and biological control ${ }^{[6]}$.

A better understanding and understanding of membrane fouling related issues is the basis for proposing effective antifouling strategies. The reported influencing factors can be divided into three categories, including operating conditions, biomass characteristics and membrane characteristics. Figure 1 shows the main factors affecting membrane fouling in MBRs. And the fouling control strategies are proposed and summarized in Table 1 .

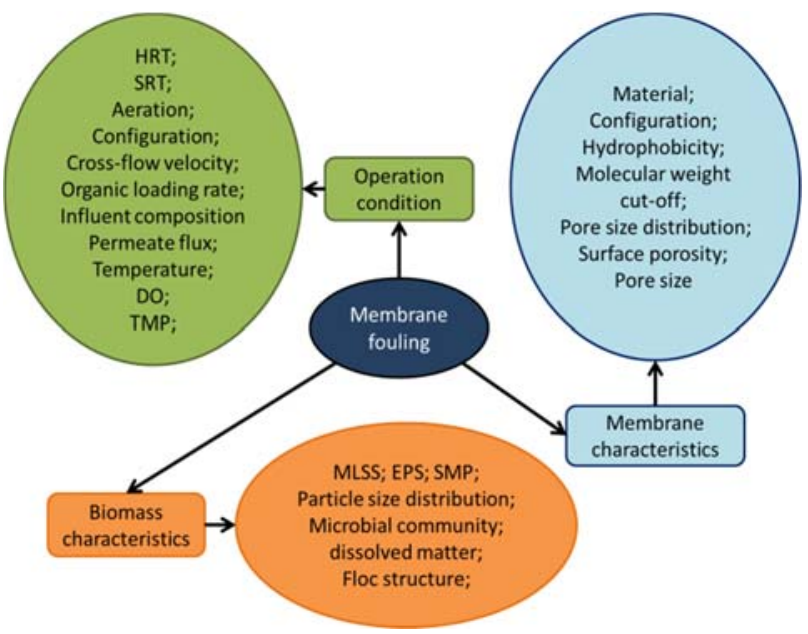

Figure 1 Important impact factors to membrane fouling in MBRs.

Table 1 Summary of antifouling strategies in MBRs.

\begin{tabular}{|c|c|c|c|c|c|c|}
\hline Class & Methods & $\begin{array}{c}\text { Target } \\
\text { foulant }\end{array}$ & Mechanisms & Advantages & Shortages & References \\
\hline $\begin{array}{c}\text { Physical } \\
\text { cleaning }\end{array}$ & $\begin{array}{c}\text { Aeration souring; } \\
\text { mechanical cleaning; } \\
\text { ultra-sonication; } \\
\text { adding carriers }\end{array}$ & $\begin{array}{c}\text { Reversible } \\
\text { fouling }\end{array}$ & $\begin{array}{c}\text { Turbulence } \\
\text { fluctuations; shear } \\
\text { stress }\end{array}$ & $\begin{array}{c}\text { Eroding the } \\
\text { deposition layer; } \\
\text { no harm to } \\
\text { membrane }\end{array}$ & $\begin{array}{c}\text { Sludge } \\
\text { deflocculation; } \\
\text { energy waste; } \\
\text { lower } \\
\text { denitrification; }\end{array}$ & [6-8] \\
\hline $\begin{array}{c}\text { Chemical } \\
\text { cleaning }\end{array}$ & $\begin{array}{c}\text { Chemical reagents, } \\
\text { such as bases, acid, } \\
\text { and oxidants }\end{array}$ & $\begin{array}{c}\text { Irreversible } \\
\text { fouling }\end{array}$ & $\begin{array}{c}\text { Solubilization and } \\
\text { neutralization; } \\
\text { hydrolysis; } \\
\text { oxidation, and } \\
\text { disinfection; }\end{array}$ & $\begin{array}{c}\text { In-situ; effective } \\
\text { and efficient }\end{array}$ & $\begin{array}{c}\text { Second pollution; } \\
\text { damage membrane }\end{array}$ & [9,10] \\
\hline $\begin{array}{c}\text { Biological } \\
\text { cleaning }\end{array}$ & $\begin{array}{c}\text { Bioactive agents } \\
\text { (enzymatic approach, } \\
\text { quorum quenching) }\end{array}$ & $\begin{array}{c}\text { Reversible } \\
\text { and } \\
\text { irreversible } \\
\text { fouling }\end{array}$ & $\begin{array}{c}\text { Mitigation of } \\
\text { biofilm formation }\end{array}$ & $\begin{array}{c}\text { No pollution; } \\
\text { environment- } \\
\text { friendly }\end{array}$ & $\begin{array}{c}\text { High demand of } \\
\text { operation; less } \\
\text { efficient than } \\
\text { chemical cleaning }\end{array}$ & {$[8,10,11]$} \\
\hline
\end{tabular}

\section{QS and QQ FOR BIOFOULING CONTROL}

Bacteria can produce, release and detect chemical signaling molecules; through this process, they can coordinate their population behaviors, such as bioluminescence, biofilm formation, antibiotic secretion, virulence expression and sporulation ${ }^{[12]}$. A schematic drawing of microbial quorum sensing manners in group is given in Fig. 2. It has been found that QS can regulate the formation of biofilms in various biological systems, including activated sludge for wastewater treatment ${ }^{[13]}$. Thus, understanding the mechanism of QS is important for biofouling control in MBR systems. N-acyl homoserine lactones (AHLs) are the most common signaling molecules used by Gram-negative bacteria and autoinducer peptides (AIPs) are used by Gram-positive bacteria, additionally, both Gram-negative and Gram-positive bacteria produce and detect autoinducer-2 $(\mathrm{AI}-2)^{[3]}$

AHLs are small amphiphilic molecules that can diffuse freely through cell membranes and enter the surrounding environment as messenger molecules. Two regulatory proteins, called LuxI and LuxR, are essential for QS. LuxI ("I" means inducer) homologous protein can synthesize AHL, and then LuxR ("R" means modulator) homologous protein can sense the local concentration of AHL and trigger a coordinated response, such as biofilm formation, extracellular polymeric substance (EPS) production, surface mobility and interspecies competition ${ }^{[14]}$. When the cell density is lower than the threshold, the AHL signal generated by LuxI diffuses passively to the outside of the cell according to the concentration gradient. At this time, the Lux operon is not expressed. However, when the cell density reaches a higher level, the QS signaling molecule produced by LuxI will bind to LuxR, and this AHL-LuxR complex will activate the transcription of the LuxI-CDABE operon. In the absence of AHL signal, LuxR is in an inactive state. Figure 3 fills in the details. 


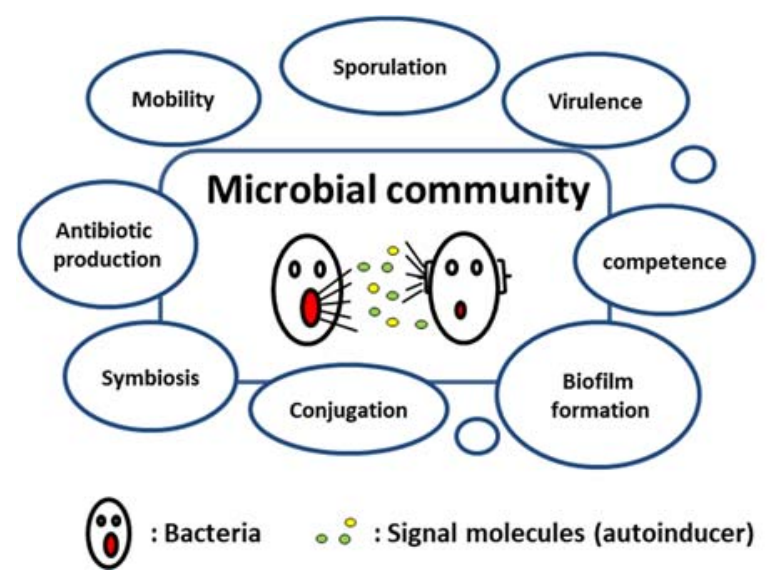

Figure 2 QS mechanism and group behaviors

Fig. 3 illustrated that QQ strategies may disrupt microbial communication are shown: (i) interrupt the synthesis of signal molecules; (ii) inactivation or degradation of signal molecules; (iii) interfere with signal receivers. In addition, stimulating the activity and/or growth of QQ bacteria in the system can inhibit the QS phenomenon.

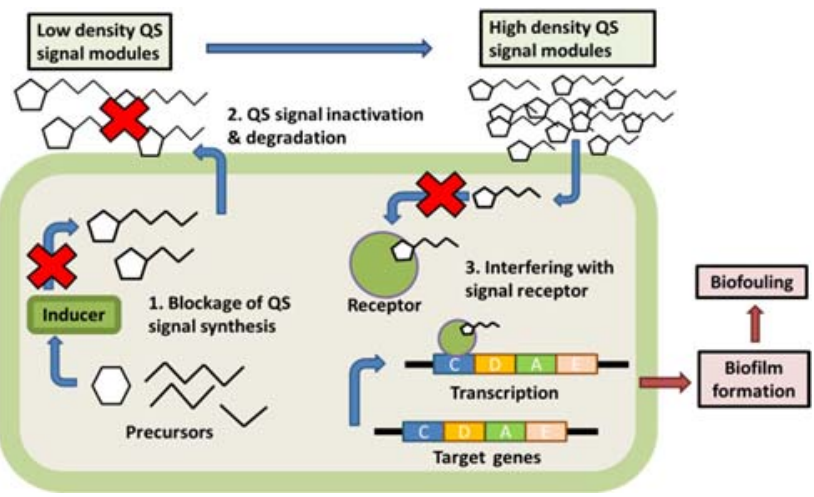

Figure 3 QS signaling routes and possible QQ strategies for biofouling control

\section{4 self-clean $Q Q$ in engineering}

In this review, we have reviewed and compiled examples of QQ MBR applications that have been developed to weaken biofouling. A summary of the studies and applications is presented in Fig. 4.

In 2009, Cataldi and his teammates published the quorum quenching MBR study firstly. They added an enzyme (Acylase) directly in the MBR to inhibit quorum sensing by breaking down signal molecules (AHLs) ${ }^{[15]}$. They verified that the addition of acyltransferase can hold up the enhancement of TMP by adjusting the EPS concentration. Lee et al. immobilized a quorum quenching enzyme (Acylase) onto a nanofiltration membrane. They concluded that QQ inhibited polysaccharides, thereby reducing the formation of biofilms on the immobilized acyltransferase membrane ${ }^{[16]}$. Oh et al. separated and determined QQ bacteria Rhodococcus sp. BH4 in a real MBR plant and arranged a polymeric microbial vessel including these QQ bacteria. Biological pollution was avoided with a success rate of $50 \%$ in this study,. The polymerized microorganism container showed reproducible QQ efficiency, which greatly delayed the rise of TMP ${ }^{[17]}$.

In addition, there are lots of studies that are creative and talk about new MBR applications of QQ. One of these novel applications is QQ-hollow cylinder, which showed higher quorum quenching activity than did the QQ beads. In addition, the shape of the QQ hollow cylinder makes the medium and the biofilm more physical contact, thereby improving the physical cleaning efficiency ${ }^{[18]}$. All the existing QQ media have their own advantages and disadvantages, and provide certain advantages. In this regard, together with innovative QQ media and new QQ microorganisms, it is expected that the development of QQ MBR research will continue to increase.

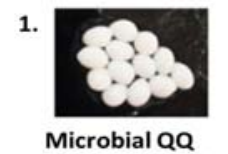

composite bead

4.

4.

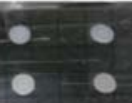

Microbial QQ

alginate bead

7.

.

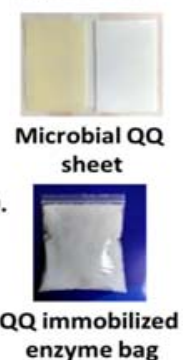

2. carrier

5.

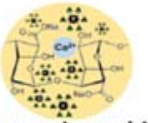

QQ enzyme immobilize alginate bead

8.
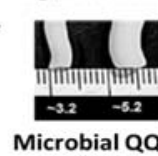

Microbial QQ

11.

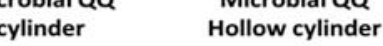

3.

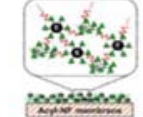

6.

9.

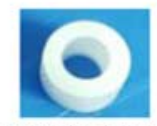

Hollow cylinder

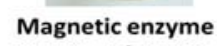

QQ enzyme immobilized

QQ enzyme bag

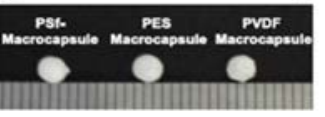

Microbial QQ macrocapsule
Figure 4 the QQ applications in MBRs

\section{Summary and perspectives}

The traditional method, directly addition, is susceptible to gas and water erosion and indigenous microorganisms in the system. Although the immobilization technology can overcome the above problems, it can still lead to the disordered distribution of engineering bacteria in the system. Therefore, in the same way as the quorum quenching technology, exploring and establishing a technology for the growth of engineering bacteria at a short distance on the membrane surface to effectively control MBR biofilm pollution is the key to the efficient application of engineering bacteria. Through integrated tube bundle and process optimization, the MBR membrane module was effectively modified to form a water-phase flow film on the membrane surface, which can not only promote the attachment and growth of self-cleaning engineering bacteria, but also effectively resisted the effects of system water and water scouring and indigenous microorganisms. Only in this way can we solve the key obstacle of effective growth of clean engineering bacteria.

\section{Conclusions}


MBR, involved in the recovery and reuse of water and wastewater, are currently plagued by a series of biofouling issues. One of the most common obstacle caused by microbial activities (i.e biofilm formation) is a natural phenomenon caused by QS. Microbial communication not only occurs in the intraspecies, but also uses different signaling molecules between interspecies. Therefore, QQ is discovered and identified to be an original and prospective technique to diminish biofouling. A couple of media with QQ enzymes and microorganisms have proven their effectiveness against membrane fouling. In order to improve the QQ technology in the MBR, further research is needed to develop more durable and robust media and vigorously promote the application of self-cleaning engineering QQ bacteria

\section{References}

1. BAGHERI M, MIRBAGHERI S A. Critical review of fouling mitigation strategies in membrane bioreactors treating water and wastewater[J]. Bioresource Technology, 2018,258: 318-334.

2. MENG F, CHAE S R, DREWS A, et al. Recent advances in membrane bioreactors (MBRs): membrane fouling and membrane material[J]. Water Res, 2009,43(6): 1489-1512.

3. KÖSE-MUTLU B, ERGÖN-CAN T, KOYUNCU I, et al. Quorum quenching for effective control of biofouling in membrane bioreactor: A comprehensive review of approaches, applications, and challenges[J]. Environmental Engineering Research, 2019,24(4): 543-558.

4. HUANG J, SHI Y, ZENG G, et al. Acyl-homoserine lactone-based quorum sensing and quorum quenching hold promise to determine the performance of biological wastewater treatments: An overview[J]. Chemosphere, 2016,157: 137-151.

5. HAM S, KIM H, CHA E, et al. Mitigation of membrane biofouling by a quorum quenching bacterium for membrane bioreactors[J]. Bioresource Technology, 2018,258: 220-226.

6. MENG F, ZHANG S, OH Y, et al. Fouling in membrane bioreactors: An updated review[J]. Water Research, 2017,114: 151-180.

7. KHATRI N, KHATRI K K, SHARMA A. Enhanced Energy Saving in Wastewater Treatment Plant using Dissolved Oxygen Control and Hydrocyclone[J]. Environmental Technology \& Innovation, 2020,18: 100678.

8. YANG C, QIU C, HE C, et al. Influence of aluminium accumulation on biological nitrification and phosphorus removal in an anoxic - oxic membrane bioreactor[J]. Environmental Science and Pollution Research, 2019,26(27): 28127-28134.

9. WANG Z, MA J, TANG C Y, et al. Membrane cleaning in membrane bioreactors: A review $[\mathrm{J}]$. Journal of Membrane Science, 2014,468: 276-307.
10. HUANG S, SHI X, BI X, et al. Effect of ferric hydroxide on membrane fouling in membrane bioreactor treating pharmaceutical wastewater[J]. Bioresource Technology, 2019,292: 121852.

11. SHENG G, YU H, LI X. Extracellular polymeric substances (EPS) of microbial aggregates in biological wastewater treatment systems: A review[J]. Biotechnology Advances, 2010,28(6): 882-894.

12. LEEA K, YUB H, ZHANG X, et al. Quorum sensing and quenching in membrane bioreactors: Opportunities and challenges for biofouling control[J]. Bioresource Technology, 2018(270): 656-668.

13. KAMPOURIS I D, KARAYANNAKIDIS $\mathrm{P} D$, BANTI D C, et al. Evaluation of a novel quorum quenching strain for MBR biofouling mitigation[J]. Water Research, 2018,143: 56-65.

14. ORTORI C A, DUBERN J, CHHABRA S R, et al. Simultaneous quantitative profiling of $\mathrm{N}$-acyl-1-homoserine lactone and 2-alkyl-4(1H)-quinolone families of quorum-sensing signaling molecules using LC-MS/MS[J]. Analytical and Bioanalytical Chemistry, 2011,399(2): 839-850.

15. CATALDI T R I, BIANCO G, ABATE S. Accurate mass analysis of $\mathrm{N}$-acyl-homoserine-lactones and cognate lactone-opened compounds in bacterial isolates ofPseudomonas aeruginosa PAO1 by LC-ESI-LTQ-FTICR-MS[J]. Journal of Mass Spectrometry, 2009,44(2): 182-192.

16. LEE J, WON Y, CHOI D, et al. Micro-patterned membranes with enzymatic quorum quenching activity to control biofouling in an MBR for wastewater treatment[J]. Journal of Membrane Science, 2019,592: 117365.

17. PAN Y, WANG Y, YAN X, et al. Quorum Quenching Enzyme APTM01, an Acylhomoserine-Lactone Acylase from Marine Bacterium of Pseudoalteromonas tetraodonis Strain MQS005[J]. Current Microbiology, 2019,76(12): 1387-1397.

18. MONZON O, YANG Y, LI Q, et al. Quorum sensing autoinducers enhance biofilm formation and power production in a hypersaline microbial fuel cell[J]. Biochemical Engineering Journal, 2016,109: 222-227. 